\title{
Baseline Survey as a Framework of Rabies Control Program in Supporting West Java to Be Rabies Free In the Year of 2018
}

\author{
Yusuf Ridwan $^{1,4^{*}}$, Etih Sudarnika ${ }^{1,4}$, Abdul Zahid Ilyas ${ }^{1,4}$, Denny W. Lukman ${ }^{1,4}$, \\ Koekoeh Santoso ${ }^{2}$, Agus Wijaya ${ }^{3}$, Ardilasunu Wicaksono ${ }^{1}$, Ronald Tarigan ${ }^{2}$, Sri Murtini ${ }^{1}$, \\ Usmah Afiff $^{1}$, Dordia A. Rotinsulu ${ }^{1}$, Ridi Arif ${ }^{1}$ \\ ${ }^{I}$ Department of Animal Disease and Veterinary Public Health \\ ${ }^{2}$ Department of Clinic, Reproduction, and Pathology \\ ${ }^{3}$ Department of Anatomy, Physiology, and Pharmacology \\ ${ }^{4}$ National Zoonoses Center \\ Faculty of Veterinary Medicine, Bogor Agricultural University \\ *Corresponding author: yusufridwan67@yahoo.com
}

\begin{abstract}
West Java province is one of 24 provinces in Indonesia, which is known as not rabies free. West Java is planned to be rabies free in the year of 2018. In supporting of West Java rabies free programs, Baseline surveys a the basis of control programs was conducted in the Jampang Tengah and Cisolok Sub-District in the District of Sukabumi, since March until October 2016. The method included laboratory examinations (blood profiles, helminths, antibody titre against rabies before and after vaccination);intervention (vaccination, deworming, and campaign); study on KAP of community towards rabies. The blood profile of dogs both in two-sub districts were in the normal range, however the value of hematrocit and the amount of Haemoglobin were slightly low. The prevalence of helminth infection in dog in Sukabumi was $20.83 \%$. Blood parasite infection rate was low $(0.6 \%$ as highest $)$, but the prevalence rate was high $(>80 \%)$. vaccination increased the number of dogs that have a protective antibody titter (from $40.5 \%$ to $77.07 \%$ in the Sub-District of Cisolok and from $20.2 \%$ to $79.83 \%$ in Sub-DistrictJampang Tengah).The knowledge of community on rabies in Jampang Tengah and CisolokSub-District was in the medium category, but the majority of people applied bad practices related to rabies.
\end{abstract}

Key words: baseline surveillance, rabies, blood profile, helminth infection, vaccination, KAP.

\section{INTRODUCTION}

Rabies is the most important zoonosis in Indonesia, because of the vast area of rabies, the high biting cases by suspected animals and its high fatality rate. In Indonesia, rabies is an endemic disease where only nine provinces are declared as rabies free. West Java province is one of 24 provinces in Indonesia, which is known as not rabies free (DITJEN P2PL, 2015). West Java is planned to be rabies free in the year of 2018. Rabies eradication efforts in West Java is very strategic considering the position of West Java which is located between rabies-free areas. In addition, some regency in West Java are dog-source supplier for several areas in Jakarta, Central Java and West Sumatra. Sukabumi is among several regencies in West Java where biting from animal and positive cases of rabies are still reported.

To achieve West-Java Province as a rabies-free area, several steps and comprehensive program are required, including approach trough the government policies, virus biology, sociology of the society and rabies transmitter animal. The main transmission of rabies is trough dogs as a pet or stray animal, which has a high mobility, therefore the elimination of rabies, must be done by controlling the dog population and dog movement control in and out from West Java Province. 
Besides the control of rabies transmitter animal, public awareness of rabies and dog keeping procedure are also very important factors. Campaign of rabies is required to involve community participation in rabies control.This initial study is targeted to have baseline data on animal health status, antibody titers of dogs against rabies before and after vaccination and baseline data on knowledge, attitude and practice of community towards rabies. This result will be used as a basis to develop rabies control program in Sukabumi District.

\section{METHODS}

\section{Study Area}

The study was conducted in the Jampang Tengah Sub-District and Cisolok Sub-District in the District of Sukabumi, since March until October 2016.

\section{Samples Collection}

The collected samples were fecal and blood samples. The fecal samples were used to examine the present of helminth infection, while blood samples were used to examine blood profile, the present of blood parasite infection and to evaluate antibody titre against rabies before and after vaccination.

\section{Study on Knowledge, Attitude and Practice (KAP)}

The data on KAP of community towards rabieswere collected through interviewing respondents using structured questionnaire

\section{Data Analyses}

Tha data were analysed descriptively and analytically.

\section{RESULT AND DISCUSSION}

The results of this study showed that the blood profile of dogs in Jampang Tengah and Cisolok Sub-District were in the normal range, however the value of hematrocit and the amount of Haemoglobin were slightly low. In the description of leukocytes it is seen a light increase in the average percentage of lymphocytes and the absolute lymphocyte count, but these conditions are common after vaccinations and excitement.

The examination of fecal samples results showed that prevalence of helminth infection in dog in Sukabumi was $20.83 \%$ caused by hookworms. The prevalent of hookworms on dog was higher in the Jampang Tengah than Cisolok Sub-District. This prevalence was associated with the age of dog, young dogs are more susceptible to helminth infection. Endrias et al. (2010) reported similar result although the infection tends higher in female dog. Another finding showed that the infections was no associated with Hematrocit and Haemoglobin level. It is touch caused by status of the infection in light category infection. Therefore, the infection does not affect the body's physiological status.

Examinations of blood parasite showed most of dog in Sukabumi were infected with blood parasite with prevalence of $92.03 \%$. The infection of blood parasite was more prevalent in Cisolok (93.75) than Jampang Tengah sub district (88.3\%). The blood parasites that infect dogs in Sukabumi were Babesia sp, Theileria sp and Anaplasma sp with the prevalence 73.91, 47.1 and $58.69 \%$ respectively. Blood parasite infection rate was low $(0.6 \%$ as highest), but the prevalence rate is high $(>80 \%)$, therefore special aware is needed if cases arise.

Collecting of blood samples was conducted before vaccination for baseline serologic of antibody titre against rabies and after vaccination for evaluation of vaccination. The result of baseline survey pre-vaccination showed that 59.5\% population dog in Jampang Tengah and 40.5\% 
population of dog in Cisolok had a protective antibody against rabies. The protective antibody titre in pre-vaccination is presumably because the dogs have been vaccinated previously and not from natural infection. According to OIE, rabies control will be effective with $70 \%$ coverage vaccination. Vaccination coverage of rabies on dog conducted in two sub-districts was $63 \%$ and 73 $\%$ for Jampang Tengah and Cisolok Sub-District respectively. The coverage of vaccination in Jampang Tengah was less than $70 \%$ in Jampang Tengah involved some factors namely lack of community knowledge of the importance of rabies vaccination program, dog handling and restraint problem, and difficulty to access of study area. Post vaccination examination of antibody titters showed an increasing population of dogs that have a protective antibody titters (as much as $77.07 \%$ in the Cisolok and 79.83\% in Jampang Tengah sub District).

The knowledge and attitude of majority community related torabies in Jampang Tengah SubDistrict and CisolokSub-District was in the medium category. However, the majority of people (63.1\%) applied bad practices related to rabies. This may be related with the educational level of the community which majority of them have only graduated of elementary school and some noneducational. The analysed result also showed that the level of community knowledge was associated with information access to rabies (Ali et al. 2013). The community that had an access to information through extension or other media have better knowledge related rabies. It showed that the role of providing information to the community through campaign or other media is very important.

\section{CONCLUSSION}

1. Dog blood profile in sub-district study area were in the range normal category, except for PCV and $\mathrm{Hb}$ in the lower level

2. The helmint prevalence on dog in Sukabumi was 20.83\%. Parasitemia level of blood protozoa was in low category, however the prevalence of blood protozoa was high.

3. Vaccination increased dog population that has protective antibody titer against rabies.

4. Knowledge and attitude of community in the study area were in middle category, however majority of community have practice in bad category about rabies control.

\section{REFERENCES}

Ali A, Ahmed EY, Sifer D. 2013. A Study on Knowledge, Attitude and Practice of rabies among residents in Addis Ababa, Ethiopia.Ethiopia Veterinary Journal 17(2):19-35.

[DITJEN

P2PL]

DirektoratJeneralPengendalianPenyakitdanPenyehatanLingkunganKementrianKesehatanRepu blik Indonesia.2015. Profil Pengendalian Penyakit dan Penyehatan Lingkungan. Jakarta (ID): Ditjen P2PL.

Endrias Z, Semahegn Y, Mekibib B (2010). Prevalence of helminth parasites of dogs and owners awareness about zoonotic parasites in Ambo town, central Ethiopia.Ethiop. Vet J, 14, 17-30. 